Alternative Theories of Illegal Trade: Economic Consequences and Statistical Detection Author(s): Jagdish N. Bhagwati

Reviewed work(s):

Source: Weltwirtschaftliches Archiv, Bd. 117, H. 3 (1981), pp. 409-427

Published by: Springer

Stable URL: http://www.jstor.org/stable/40438952

Accessed: $31 / 01 / 2013$ 14:45

Your use of the JSTOR archive indicates your acceptance of the Terms \& Conditions of Use, available at http://www.jstor.org/page/info/about/policies/terms.jsp

JSTOR is a not-for-profit service that helps scholars, researchers, and students discover, use, and build upon a wide range of content in a trusted digital archive. We use information technology and tools to increase productivity and facilitate new forms of scholarship. For more information about JSTOR, please contact support@jstor.org. 


\title{
Alternative Theories of Illegal Trade: Economic Consequences and Statistical Detection
}

By

\author{
Jagdish N. Bhagwati
}

Contents: I. Different Types of Illegal Trade. - II. Some Key Concepts. - III. Alternate Models: A. Illegal Trade through Legal Entry Points; B. Illegal Trade through Illegal Entry Points. - IV. Concluding Remarks.

$\mathrm{R}$ ecently, the theoretical analysis of illegal trade has received fresh impetus from the imaginative work of Mark Pitt [198r]. The earlier analysis (initiated by the Bhagwati and Hansen [1973] paper and extended in subsequent contributions by Johnson [1974], Sheikh [1974] and others) had assumed that legally and illegally traded goods, as long as they were homogeneous, would be cleared in the domestic market at identical prices, and that this identical price would have to be equal to the tariff-inclusive price on legal trade since any domestic price below that would make legal trade unprofitable.

Observing that legal trade in Indonesia co-exists with illegal trade and that despite this the domestic price is below the tariff-inclusive price (so that legal trade is presumably unprofitable), Pitt constructs a model that permits such "price disparity" to exist in the model. Basically, he argues that some legal trade is required if the trader is to handle illegal trade without unnecessary risk of detection; hence the loss on legal trade is to be seen as a way of permitting the profits on illegal trade to be earned.

Pitt's ingenious work opens up therefore the question as to how illegal trade is optimally analyzed, and how it may then be best detected in empirical analysis. In the following analysis, I take the view that reality is complex and that there are different ways in which illegal trade will

Remark: Thanks are due to the Guggenheim Foundation and the National Science Foundation for research support. In synthesizing and extending the theoretical work on modelling illegal trade, I have drawn on much earlier research where I collaborated with Bent Hansen and T. N. Srinivasan. To these distinguished economists, as also to Mark Pitt [198I] whose paper provided the immediate impetus to write the present paper, I wish to express my thanks. I have also profited from conversations with Richard Brecher and Padma Desai and from the stimulating reactions of participants in seminars arranged by the Ford Foundation at the University of Philippines, the Bank of Indonesia and Thammasat University in Thailand. The comments of Mark Pitt have been most helpful, especially in correcting an $i^{\text {mportant error. }}$ 
arise; that therefore there are different ways in which they need to be modelled and their positive and normative consequences analyzed; and there are correspondingly different ways in which they might be empirically detected. I therefore take successive models of illegal trade below and consider them from the viewpoint of both their economic consequences and attendant implications for their detection.

\section{Different Types of Illegal Trade}

There are two basic types of illegal trade that need to be distinguished in the following, all triggered by either quantitative restrictions, which may be set in pure quantity or (as is more frequently the case) in value terms, or by tariffs. (i) The illegal trade may simply consist in bringing the goods through legal checkpoints but bypassing the control of the customs by simply bribing the customs officer or by concealing the importation in one form or another. (ii) On the other hand, the illegal trade may be conducted through illegal checkpoints, as in the popular conception of dhores pulling in from Bahrain et al. onto inadequately patrolled coastlines and offloading their illegal cargos.

The distinction between illegal trade through legal and illegal places of entry is of importance insofar as it has a bearing on the kinds of illegal trade that can arise in the two cases. Thus, if illegal trade takes place through illegal entry points, such trade is surely likely to be that associated with "ships in the night" type of operation, which will in turn imply that definite real costs will be incurred in undertaking it. On the other hand, the illegal trade that arises in the shape of faked invoicing, where trade values are faked in order to reduce assessed payments or to increase assessed subsidies, evidently requires that such illegal trade occur through legal checkpoints where customs officers will confront the faked invoices in determining the tax payments or subsidy benefits on the alleged trade. Such faked invoicing is unlikely to involve the kinds of real costs that are associated with smuggling through illegal entry points and will therefore have differential implications, in consequence. In the analysis that follows in this paper, therefore, I will initially begin with those types of illegal trade that are typically associated with legal entry points, and then turn to the illegal trade that comes in through illegal entry points.

\section{Some Key Concepts}

In addition, the analysis below will focus on certain key concepts of "price disparities," distinguishing several types of relevant price discrepancies other than that noted by Mark Pitt, as also other disparities. 
These will be of importance in yielding statistical methods of detecting the alternative types of illegal trade in the real world. I will also confine the analysis to import tariffs throughout.

Thus, define the following symbols (assuming in each case that they relate to a specific imported good):

$p_{f}$ the f.o.b. price of the commodity, as recorded in partner-country's export data, plus estimated insurance and freight where excluded;

$\mathrm{p}_{\mathrm{c}}$ the landed price of the commodity, as declared in valuation to customs when trade is through legal entry points;

$\mathrm{p}_{\mathrm{c}}^{\mathrm{t}}$ the landed price of the commodity, as it "truly" is as distinct from its declared value which may be faked, excluding the cost of misinvoicing, $\alpha$, below;

$\mathrm{p}_{\mathrm{d}}$ domestic price of the commodity (assuming no further distinction between wholesale, retail, internal transportation charges between different locations etc.);

$\mathrm{q}_{\mathrm{f}}$ the foreign, recorded export quantity of the commodity;

$\mathrm{q}_{\mathrm{c}}$ the recorded import quantity of the commodity;

$t$ the legal tariff rate;

$t_{e}$ the "effective" (i.e. actual) tariff rate;

$\alpha$ the unit cost charged by exporter to fake importer's invoice and make underinvoiced importation possible;

$\beta$ the unit bribe paid to customs officers to overlook misinvoicing.

The distinction between legal and illegal trade, when relevant, is to be denoted by an added suffix, $l$ for legal and $i$ for illegal trade. With this notation, the following concepts may now be defined:

(I) Landed Value versus Domestic Price (LVDP) Price Disparity

This price disparity implies that $p_{c}(1+t) \neq p_{d}$, i.e. that the domestic price of the commodity is different from - in fact, is below - the tariffinclusive, landed, declared value of the commodity, implying losses on the imports of the commodity.

(2) "True" Landed Value versus Domestic Price (TLVDP) Price Disparity

Where the declared and the "true" values differ, the LVDP measure must be distinguished from the TLVDP measure such that $p_{c}^{t}(1+t) \neq p_{d}$. This is presumably Pitt's price disparity.

(3) Partner-Country-Comparison (PCC) Price Disparity

In this case, there is a discrepancy between the declared unit value (price) of a commodity in the records of the exporting and importing 
countries, when these are duly adjusted for differences in freight and insurance. This implies that $p_{f} \neq p_{c}$.

\section{(4) PCC Quantity Disparity}

Again, there may be disparity in recorded quantities in partnercountry trade data, i.e. $q_{f} \neq q_{c}$.

\section{(5) PCC Value Disparity}

Similarly, there may be total value disparity in partner-country data, i.e. $p_{f} q_{f} \neq p_{c} q_{c}$, reflecting $p_{f} \neq p_{c}$ and $/$ or $q_{f} \neq q_{c}$.

\section{(6) Legal versus Illeyal Trade (LI) Price Disparities}

Finally, one may have discrepancies between the prices in legal and illegal trade, implying for instance that either $\mathrm{p}_{\mathrm{d} l} \neq \mathrm{p}_{\mathrm{di}}$, i.e. the domestic price of a commodity is different depending on whether it is legally or illegally imported; or $\mathrm{p}_{\mathrm{cl}}^{\mathrm{t}} \neq \mathrm{p}_{\mathrm{ci}}^{\mathrm{t}}$, i.e., the true cost of importation in legal and illegal trade is different.

\section{Alternate Models}

In the following analysis, I consider altogether 6 different models, of which 4 are based on the assumption that illegal trade is conducted through legal entry points whereas the remaining 2 are formulated on the premise that it is conducted through illegal points of entry ${ }^{1}$. The analysis, it should be reemphasized, is confined to tariffs and to imports: but it can be readily extended, mutatis mutandis, to quantity restrictions and to exports. Moreover, none of the models considered here allows for the illegally imported, homogeneous goods to be transacted in the domestic market at prices different from legally imported goods, thus imposing on them identical prices at identical locations regardless of how they are imported. This assumption may not make sense in reality as transacting in illegally-imported goods may impose a discount on them. Moreover, when it comes to durables, the extended service and maintenance components of the goods may simply not be available on illegally-imported goods; also the assurance of quality may not be identical when a consumer buys around the dark corner as when he buys from a well-heeled shopkeeper handling legally-imported goods. While this possible element of reality is assumed away in the six models considered below, many other complexities are

\footnotetext{
1 These models represent polar types and reality reflects, at times, combinations thereof. Thus, faked invoicing may involve both unit-value and quantity faking; and it may involve both bribing of customs and sharing gains from faking with the exporter, whereas the four possibilities are modelled below as exclusive of one another.
} 
allowed for and the models offer important abstractions of the kinds of illegal-trade phenomena to be encountered in practice.

\section{A. Illegal Trade through Legal Entry Points}

Where illegal trade occurs through legal entry points, i.e., where it is actually declared and passed through customs, the manner in which it occurs must involve some form of faked invoicing. A few observations are in order before the analysis is undertaken.

Note first that faked invoicing may be undertaken without the bribeinduced cooperation of customs officers. Alternatively, it may be undertaken with such cooperation. The implications of the two methods of faking invoices to secure illegal importation are different since the former is likely to involve a (direct) real cost to the country insofar as the faking will require the collaboration of the exporter at greater risk and hence compensation whereas the latter requires a bribe which is, in economic terms, only a transfer payment between nationals of the importing country ${ }^{1}$.

Moreover, an implication of both basic model types here is that they blur the meaningfulness of the popular distinction between legally and illegally imported goods. For, in either case, the goods come in through legal channels but with illegal assessments of charges.

Furthermore, the analysis below builds on the distinction between faking that concerns quantity declarations and that which works through false price (or unit value) declarations: the implications are again different. Finally, it should be noted that the analysis deployed here assumes throughout that an import tariff creates an economic incentive to underinvoice so as to avoid the full tariff. However, as was noted in the articles by Bhagwati [1964; I967] which initiated the analysis of faked invoicing by using partner-country trade data comparisons, this does not always follow. For example, in countries with exchange control regimes and black market premia on foreign exchange, the faking incentive will be to overinvoice imports when the tariff rate is below the black market premium on foreign exchange; and it will be to underinvoice, as assumed throughout here, when the tariff rate exceeds the black market premium (as would automatically be the case under full convertibility).

\footnotetext{
${ }^{1}$ It is conceivable, of course, that the illegal trade is transacted by foreign nationals, as noted by Bhagwati and Hansen [1973] in their early analysis of smuggling. In that event, the argument in the text would need to be suitably modified.
} 


\section{Model I: Faked Invoicing of Unit Values or Prices, without Bribing of Customs}

In this case, the faking of the invoice, so as to underinvoice imports, occurs through understatement of the unit value at which the quantities (which are correctly invoiced) are imported.

Such underinvoicing may occur costlessly to the importer, and hence to the country (assuming that the importer is a national), in the sense that the exporter is prepared to give the importer the faked invoice at negligible cost. Alternatively, it may occur at a non-negligible real cost, as when the importer has to share some fraction of his resulting gains with the exporter to induce him to supply the necessary faked invoice. The latter may be a possibility if the trade in the commodity is by reputable firms and is subject to a non-negligible prospect of detection: in which case the risk of potential damage to the exporter from detection is non-negligible and hence may require inducement in the form of a share in the gains from underinvoicing. The welfare implications as also some of the "positive" implications will be different in each of the two cases.

Case $(I)$ : Consider first the case where the real cost to the importer of faking the invoice is negligible. What are then the consequences for the different "disparities" distinguished above? Now, the effective tariff rate will be: $t_{e}=t p_{c} / p_{c}^{t}$ since $p_{d}=p_{c}^{t}+t p_{c}$. Therefore, the following consequences can be noted.

(i) With $\mathrm{p}_{\mathrm{c}}<\mathrm{p}_{\mathrm{c}}^{\mathrm{t}}$ due to underinvoicing of imports, $\mathrm{p}_{\mathrm{d}}>\mathrm{p}_{\mathrm{c}}(1+\mathrm{t})$ and therefore $L V D P$ price disparity, which relates to the declared unit value, will exist. However, it will exist with a reversed sign from Pitt's: importation will appear as if it was yielding "abnormal" profits.

(ii) Next, TLVDP price disparity will also exist, with Pitt's sign, with $\mathrm{p}_{\mathrm{c}}^{\mathrm{t}}(1+\mathrm{t})>\mathrm{p}_{\mathrm{d}}\left(\right.$ as $\mathrm{p}_{\mathrm{c}}<\mathrm{p}_{\mathrm{c}}^{\mathrm{t}}$ and $\left.\mathrm{p}_{\mathrm{d}}=\mathrm{p}_{\mathrm{c}}^{\mathrm{t}}+\mathrm{t} \mathrm{p}_{\mathrm{c}}\right)$.

(iii) At the same time, PCC price disparity will arise since the recorded, true export price (or unit value) will exceed the declared, understated import price, i.e., $\mathrm{p}_{\mathrm{f}}>\mathrm{p}_{\mathrm{c}}$.

(iv) PCC quantity disparity will not arise, of course: $\mathrm{q}_{\mathrm{f}}=\mathrm{q}_{\mathrm{c}}$.

(v) But PCC value disparity will, since $\mathrm{p}_{\mathrm{f}} \mathrm{q}_{\mathrm{f}}>\mathrm{p}_{\mathrm{c}} \mathrm{q}_{\mathrm{c}}$.

(vi) Finally, there are no $L I$ price disparities: legal and illegal trade are not meaningfully distinguishable in the fully competitive case, since all trade will be costlessly underinvoiced.

The implications for statistical detections of this kind of illegal trade are evident. Price disparities of the LVDP, TLVDP and PCC variety have to be looked for. The TLVDP price disparity would require extracting the 
"true" landed value. This and the PCC price and value disparities may be spotted through a careful use of the partner-country trade comparison technique which has been developed in Bhagwati [I964] who analyzed the faked invoicing of Turkish imports and in many other papers ${ }^{1}$.

The welfare implications of such illegal trade are easily seen if a conventional social-utility-function approach is taken. In the BhagwatiHansen [I973] $2 \times 2$ model, the effect as illustrated in Figure I (adapted from Bhagwati and Hansen) is seen readily as that of a simple reduction

Figure I

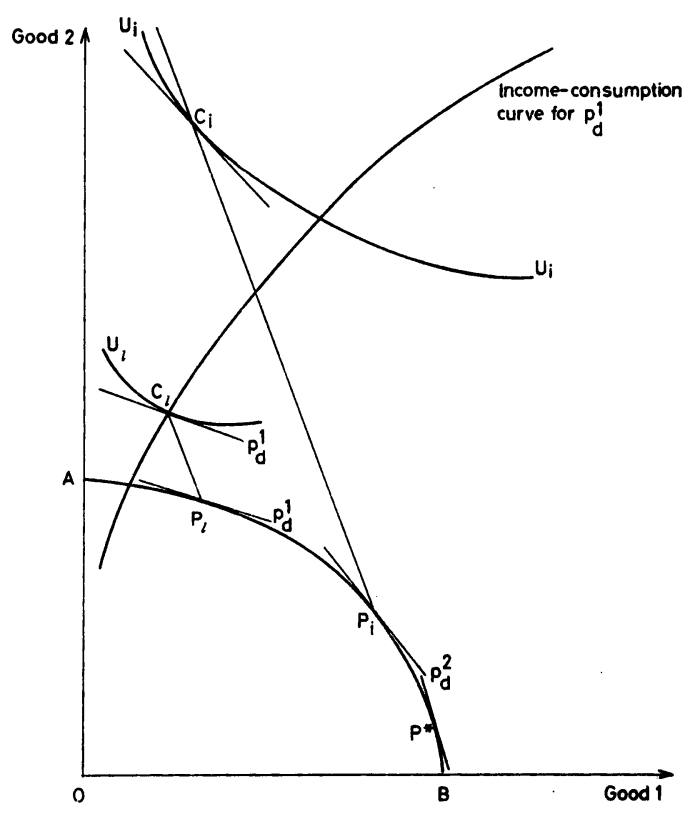

in the "effective" tariff level. Thus, in the legal case without faked invoicing, the tariff-inclusive domestic goods price-ratio is $\mathrm{p}_{d}^{1}$ and consumption, production and welfare are at $\mathrm{C}_{l}, \mathrm{P}_{l}$ and $\mathrm{U}_{l}$, respectively. With reduction in effective tariff, the goods price-ratio shifts to $p_{d}^{2}$ and consumption, production and welfare to $C_{i}, P_{i}$ and $U_{i}$, respectively. $U_{i} \geqslant U_{l}$ necessarily obtains since, ruling out inferior goods and associated multiple equilibria, a lower tariff will not be inferior to a higher tariff.

\footnotetext{
1 Essentially, the analyst has to be able to correct for the many statistical reasons for discrepancies in PCC trade data, to be able to sift through to the faking that is sought to be pinned down. For a fuller discussion, see Bhagwati [1964; 1967] and Bhagwati et al. [1974].
} 
Of course, this conclusion is strictly limited to conventional welfare analysis. If import substitution, for instance, were valued as a "noneconomic" objective or if revenues were important, the analysis would have to be suitably amended - as already done by several theorists of illegal trade for Model V below. Again, the sheer fact of illegality may constitute a negative element in the evaluation of the overall welfare impact. This factor is ignored in this paper but can be suitably allowed for in a fuller analysis. Equally, non-economic and revenue objectives can be allowed for: these are ignored here so as to focus rather on the major distinctions among the different models of illegal trade ${ }^{1}$.

Case 2: Consider now the other case where the faked invoicing requires non-negligible real cost via sharing a fraction of the importer's gains from faking with the foreign exporter. This will modify critically the disparity and welfare outcomes. Note now that, with $\alpha$ representing the unit cost charged by the exporter to fake invoices for the importer, we have $p_{d}=$ $\mathrm{p}_{c}^{t}+t \mathrm{p}_{c}+\alpha$. Therefore, the effective tariff is $t_{e}=\left(t p_{c}+\alpha\right) / p_{c}^{t}$. The following consequences then arise for disparities.

(i) With $\mathrm{p}_{\mathrm{c}}<\mathrm{p}_{\mathrm{c}}^{\mathrm{t}}$ due to underinvoicing of imports, we again have $\mathrm{p}_{\mathrm{d}}>\mathrm{p}_{\mathrm{c}}(1+\mathrm{t})$. Therefore, LVDP price disparity again exists, with the reversed sign from Pitt's.

(ii) At the same time, TLVDP price disparity will also arise, with Pitt's sign, since $\left\{\mathrm{p}_{\mathrm{c}}^{\mathrm{t}}(1+\mathrm{t})-\mathrm{p}_{\mathrm{d}}\right\}=\mathrm{t}\left(\mathrm{p}_{\mathrm{c}}-\mathrm{p}_{\mathrm{c}}^{\mathrm{t}}\right)+\alpha<0$ as $\alpha>0$ but cannot exceed in absolute magnitude the total gain from underinvoicing measured by $\mathrm{t}\left(\mathrm{p}_{\mathrm{c}}^{\mathrm{t}}-\mathrm{p}_{\mathrm{c}}\right)$.

(iii) PCC price disparity will exist whether $\mathrm{p}_{\mathrm{f}}$, the recorded export value adjusted for insurance and freight, includes the share in the gain from faking or not. In the former case, the disparity will be smaller.

(iv) PCC quantity disparity does not exist, of course.

(v) PCC value disparity will exist, reflecting the price disparity.

(vi) $L I$ price disparity cannot arise.

The major difference in disparities when the faking of unit values occurs with real cost therefore is that the real cost now implies that the reduction in the domestic goods price-ratio, $\mathrm{p}_{d}$, that follows is no longer an unmixed gain. For, it is accompanied by a terms-of-trade loss as a result of the "true" landed price rising by the amount of the gain from faking that is shared with the foreign exporter. Therefore, as Bhagwati

1 The contrasting implications of different models for issues such as the rank-ordering of the maximal revenue tariff with and without illegal trade are treated, for Models V and VI below, in Pitt [1981] for instance. 
and Hansen [I973] demonstrated, the net welfare impact may be a gain or a loss. The reader can readily illustrate this by modifying Figure I to compare a (legal) higher-tariff situation with a (faked, illegal) lower-tariff situation, but with the latter now characterized by inferior terms of trade.

\section{Model II: Faked Invoicing of Quantity, without Bribing of Customs}

In this case, the faked invoicing occurs via misstatement of the quantity being imported. Typically, the containers may contain a larger quantity than invoiced. This rather common form of illegality may be safely assumed to require non-negligible real resource cost since quantity faking is more detectable than unit value faking and therefore more risky to the exporter's goodwill and future business, requiring therefore some compensation. It is also likely to involve special packing, which may be more expensive. In this case, the following consequences arise.

(i) LVDP price disparity will exist because the effective tariff will have been lowered and therefore $p_{c}(1+t)>p_{d}$, with $t>t_{e}$.

(ii) Similarly, TLVDP price disparity will also exist, with $\mathrm{p}_{\mathrm{c}}^{\mathrm{t}}(1+\mathrm{t})$ $>\mathrm{p}_{\mathrm{d}}$ since $\mathrm{p}_{\mathrm{c}}^{\mathrm{t}}=\mathrm{p}_{\mathrm{c}}$.

(iii) If the recorded export data include the exporter's share in the gain from faking, $\mathrm{p}_{\mathrm{f}}>\mathrm{p}_{\mathrm{c}}$ and the $P C C$ price disparity will exist.

(iv) At the same time, since quantities are being faked, $P C C$ quantity it isparity must evidently exist: $\mathrm{q}_{\mathrm{f}}>\mathrm{q}_{\mathrm{c}}$.

(v) This will imply that PCC value disparity will exist: $p_{\mathrm{f}} \mathrm{q}_{\mathrm{f}}>\mathrm{p}_{\mathrm{c}} \mathrm{q}_{\mathrm{c}}$.

(vi) $L I$ price disparities will not arise under competitive import trade (unless differences are introduced in the ability of different importers/ economic agents to manage illegal faking).

The significant difference between unit-value and quantity faking, i.e. between Models I (2) and II, is then clearly that the latter generates the LVDP price disparity with the Pitt inequality sign whereas the former does with the sign reversed, thus providing the analyst with a method of discriminating between these two types of faking that may sometimes work. So also the PCC comparisons, properly conducted, may be able to distinguish between cases where the value discrepancies arise from unit price as distinct from quantity differences.

The nature of the welfare consequences, of course, is identical between the two models: since the (direct) real cost of faking is positive, both models leave open the possibility of a loss from the faking, even though the domestic price of the importable is reduced. 


\section{Model III: Faked Invoicing of Unit Values, with Bribes}

Consider now the case where Model I is modified so as to permit bribing of customs officers. This will change the picture insofar as the faking of invoices poses much-diminished risk of detection at the border now. Thus, one may consider the possibility of non-negligible resource costs (as against "transfer payments") being involved here as relatively remote and hence unnecessary to analyze. In the case where these real costs are negligible, therefore, the following disparity results follow:

(i) For LVDP price disparity, the results are naturally identical to those of Model I (2): the price disparity does arise. The identity arises because, whereas in Model I (2) the domestic price $p_{d}$ reflects element $\alpha$ (the real cost to the importer of the sharing of the gain from faking with the exporter) in the present model it reflects instead element $\beta$ (the financial cost to the importer of the bribe paid to the customs officer). Elements $\beta$ and $\alpha$ play, therefore, identical roles in regard to LVDP price disparity but, as noted below, are different in their welfare implications.

(ii) Again, TLVDP price disparity will arise, as with Model I (2). For, $\left\{\mathrm{p}_{\mathrm{c}}^{\mathrm{t}}(1+\mathrm{t})-\mathrm{p}_{\mathrm{d}}\right\}=\mathrm{t}\left(\mathrm{p}_{\mathrm{c}}-\mathrm{p}_{\mathrm{c}}^{\mathrm{t}}\right)+\beta<0$ as $\beta>0$ but cannot exceed in absolute magnitude the total gain from underinvoicing measured by $\mathrm{t}\left(\mathrm{p}_{\mathrm{c}}^{\mathrm{t}}-\mathrm{p}_{\mathrm{c}}\right)$.

(iii) PCC price disparity evidently exists, $\mathrm{p}_{\mathrm{f}}>\mathrm{p}_{\mathrm{c}}$, since the declared value in the importing country is faked at a lower value.

(iv) Quantities are not faked, so $\mathrm{q}_{\mathrm{f}}=\mathrm{q}_{\mathrm{c}}$, i.e., PCC quantity disparity does not arise.

(v) PCC value disparity will exist because $\mathrm{p}_{\mathrm{f}} \mathrm{q}_{\mathrm{f}}>\mathrm{p}_{\mathrm{c}} \mathrm{q}_{\mathrm{c}}$.

(vi) $L I$ price disparities will not exist under competitive import trade by uniform economic agents.

As for conventional welfare implications, Model III implies a straightforward cut in the effective tariff charged. Therefore, as with Model I (I) where also the real costs of faking are negligible, the effect is to increase welfare unambiguously.

\section{Model IV: Faked Invoicing of Quantity, with Bribes}

In this case, the customs officer clears an understated quantity of imports, charging the legal duty on a fraction of the actual imports. The rationale for this practice is obvious. The customs officer, to protect himself, must show some legal imports of the item and faces a seriously enhanced prospect of detection if no legal imports are registered at all. There is, therefore, some fraction of overall imports that will be declared for 
legal-duty-rate assessment. However, the effective tariff rate will be reduced since the actual imports will exceed the imports on which duty is assessed. Therefore, the practice embodied in Model IV amounts to simply cutting the actual, effective tariff rate. And it is done at negligible real cost since the bribing of the customs officer (constituting a transfer payment, and hence a financial rather than real cost) makes it unnecessary to share the gains from faking with exporters or to incur extra costs of packaging to avoid detection etc $^{1}$. The results are therefore fairly straightforward.

(i) Since the effective tariff is lowered, while the declared unit value or price is not faked, the domestic price will be lower than the landed price inclusive of the ineffective, legal tariff: $\mathrm{p}_{\mathrm{c}}(1+\mathrm{t})>\mathrm{p}_{\mathrm{d}} \cdot{ }^{2}$ LVDP price disparity will therefore obtain.

(ii) Similarly, since $\mathrm{p}_{\mathrm{c}}=\mathrm{p}_{\mathrm{c}}^{\mathrm{t}}, T L V D P$ price disparity also follows.

(iii) PCC price disparity does not obtain, since it is quantities that are faked.

(iv) The quantity faking implies that $\mathrm{q}_{f}>\mathrm{q}_{c}$, so that PCC quantity disparity obtains.

(v) PCC value disparity follows: $\mathrm{p}_{\mathrm{f}} \mathrm{q}_{\mathrm{f}}>\mathrm{p}_{\mathrm{c}} \mathrm{q}_{\mathrm{c}}$.

(vi) $L I$ price disparities do not obtain under competitive imports with uniform agents.

The welfare implications are also straightforward. The absence of real costs in faking, combined with the fact that the model implies a cut in the effective tariff, mean that unambiguous welfare improvement results.

\section{B. Illegal Trade through Illegal Entry Points}

The other, major class of illegal trade is what occurs through illegal entry points. This trade fits better the popular conception of illegality, of course. In this case it is conceivable, but highly improbable, that there

\footnotetext{
${ }^{1}$ As noted later, therefore, this model, while it is built on the notion of some legal trade permitting some illegal trade, à la Pitt [198r], departs radically from it in terms of its economic implications. In fact, Model IV makes it somewhat meaningless to distinguish between legal and illegal trade since all trade is illegal here: some fraction of it is recorded and some not. Pitt's model, Model VI below, instead makes more sense when the legal trade is through legal channels and the illegal trade is through illegal channels, the trader handles both sources of imports, and the legal imports make it possible for the trader to escape detection on his handling of the illegal imports.

2 The domestic price, $\mathrm{pd}_{\mathrm{d}}$, will reflect of course the bribe to the customs officer. It is only if the bribe fully absorbs the gain from faking that there will be equality of $p_{c}(1+t)$ and $p_{d}$, eliminating the LVDP price disparity. But that is only a limiting, and improbable, case.
} 
are no significant real costs involved in the illegal trade. Typically, costs will result from damage in transit owing to the highly unorthodox methods of transportation involved and owing to the risks of detection ${ }^{1}$. Besides, unlike in the case of illegal trade through faking at legal entry points, the distinction between legal and illegal trade is now clearly meaningful.

There are two major classes of models that exist now in the literature that seek to embody such illegal trade into general equilibrium analysis. These are discussed below, and their consequences for disparities and welfare spelled out.

\section{Model V: Smuggling of Untaxed Commodities by Firms Engaging in Illegal Trade}

In this model, the illegal and legal trade are assumed to be carried out by separate firms, with illegally imported commodities clearing in the market alongside with homogeneous, legally imported commodities at identical prices (whenever legal and illegal trades co-exist). This is the model in the early analysis of Bhagwati and Hansen [1973], and in the papers subsequently written by many authors such as Johnson [1974], Bhagwati and Srinivasan [1974], Falvey [1978], Ray [1978] and others. It also is the model underlying the analysis of Sheikh [I974]. In contrast however to Bhagwati and Hansen's assumption that the real costs of illegal trade (are higher than those of legal trade and) are incurred in the form of the traded commodities themselves (much like Samuelson's famous "melting ice" assumption for dealing with transport costs), Sheikh assumes instead that these added costs are incurred in the form of an intermediate good that uses primary factors directly.

The contrast between the Bhagwati-Hansen and Sheikh methods of modelling the added real costs of illegal trade has implications for welfare under certain conditions; but these are of no immediate concern in the present context ${ }^{2}$. Hence, the precise analysis below will assume that the Bhagwati-Hansen model is relevant: so that the added costs of illegal trade can be portrayed as simply amounting to the importing country facing a less favourable foreign offer curve on illegal trade.

Now, this model reduces in principle to Models I (2) and II (assuming that bribery is negligible in this type of illegal importation). However, aside from the fact that the price-disparity implications will be different

\footnotetext{
1 Bhagwati and Hansen [1973] mention the gruesome example of slaves being thrown overboard in the infamous slave trade after abolition when detection was imminent, so that more slaves were "lost" in illegal transit than if the trade were legal.

2 Thus, if legal and illegal trade co-exist, the Bhagwati-Hansen model implies necessary welfare loss from illegal trade. Not so, under the Sheikh model.
} 
in the present instance, an important difference is that the effective tariff on illegally imported goods now will be zero whereas in Models I (2) and II it will not be. Therefore, in depicting the economic analysis of Model V, Figure I must be modified to show the illegal trade as occurring at zero tariff rather than at just a reduced tariff.

Thus, in Figure 2, which illustrates for simplicity the case of constant costs in illegal and legal transformation and also a case where illegal trade dominates and drives out legal trade, the legal trade equilibrium in absence of smuggling is portrayed with consumption, production and welfare

Figure 2

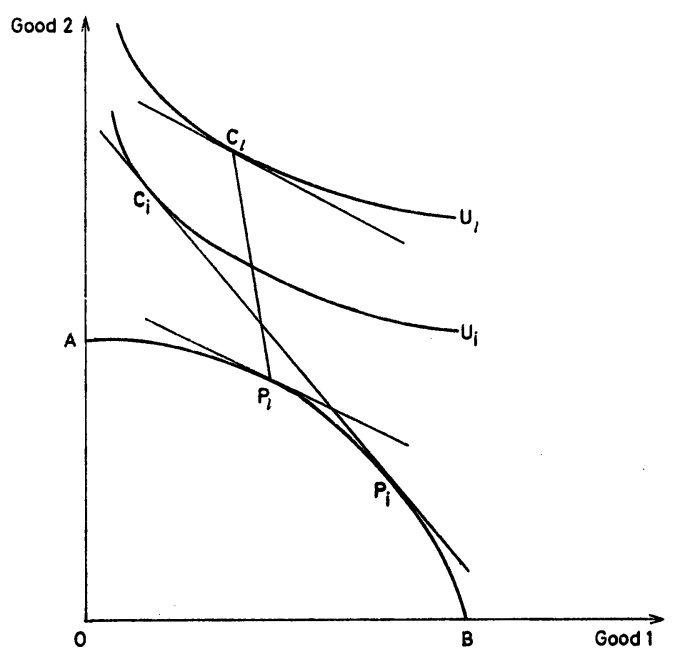

at $C_{l}, P_{l}$, and $U_{l}$, respectively, and with illegal trade at $C_{l}, P_{i}$, and $U_{i}$, respectively. Here $U_{i}<U_{l}$, though one could well have shown that $\mathrm{U}_{\mathrm{i}}>\mathrm{U}_{l} .{ }^{1}$ The welfare implications of Model V, given the terms-of-trade deterioration implied by the added costs of illegal trade, are therefore not unambiguous. The disparity implications are as follows:

(i) On legal (recorded) trade, where it exists, LVDP price disparity does not arise: $p_{c l}(1+t)=p_{d}$.

(ii) Similarly, since $\mathrm{p}_{\mathrm{cl}}=\mathrm{p}_{\mathrm{cl}}^{\mathrm{t}}, T L V D P$ price disparity also does not exist.

1 Cases where illegal and legal trade co-exist have been illustrated and discussed in Bhagwati and Hansen [1973]. 
(iii) For PCC disparities, the answer depends on whether the illegal importation is recorded or not in the exporting country's statistics ${ }^{1}$. The PCC price disparity will, however, be non-existent regardless.

(iv) PCC quantity disparity will arise, $\mathrm{q}_{\mathrm{f}}>\mathrm{q}_{\mathrm{cl}}$, if the exporting country records the illegal trade - which is perfectly possible since the illegality is in importation; it will not arise, $\mathrm{q}_{\mathrm{f}}=\mathrm{q}_{\mathrm{cl}}$, if it does not.

(v) PCC value disparity will arise or not, depending on whether PCC quantity disparity does.

(vi) LI price disparity can now meaningfully exist as illegal and legal trades can always be differentiated. Since there is an added real cost to illegal trade, this will imply that $\mathrm{p}_{\mathrm{cl}}^{\mathrm{t}}<\mathrm{p}_{\mathrm{ci}}^{\mathrm{t}}$.

\section{Model VI: Smuggling of Untaxed Commodities by Firms Engaging Simul- taneously in Legal and Illegal Trade}

Pitt [I98I] departs from the above model and essentially argues that the legal trade is undertaken so as to make illegal trade possible (at reduced risk $)^{2}$. In this case, illegal trade cannot be undertaken by itself - as it, of course, is in practice in cases where there are outright prohibitions on legal importation. Once this link is established, legal trade can arise even at a loss as long as the loss is offset by the gain on the illegal trade that the legal trade makes possible ${ }^{3}$.

Since the illegal trade occurs through illegal entry points in the present case, the present model assumes that the illegal trade occurs at an augmented real cost. The following implications then follow.

1 For detecting unrecorded trade see also Nayak [1977].

2 Pitt [1981] himself seems to imply that this model would work for illegal trade through legal entry points. Thus, he argues: "A large share of smuggling occurs not via 'ships in the night' but rather in broad daylight off the wharves of customs administered ports. Traded goods are misweighed, misgraded, misinvoiced or not invoiced at all with or without the cooperation of customs authorities. Some legal trade is necessary for this type of activity. The greater the legal trade [by a trading firm], the easier it is to hide smuggling activity from enforcement agencies and therefore the less costly will be smuggling. Thus, legal trade can be viewed as an input into the smuggling activity." However, illegal trade that occurs through legal entry points, such as customs administered wharves, involves surely some form of misinvoicing that must imply one of the four Models I-IV distinguished above, depending on whether the customs officers are bribed or not and on whether the misinvoicing implies unit value or quantity faking. Pitt's argument that legal trade is required to support illegal trade, as developed by him, is surely more appropriate when the illegal trade is through illegal entry points, whether the offloading of the illegal trade is by day or by night!

8 The loss on legal trade does not necessarily arise in all variants of this model. One cannot rule out, in general, the possibility that both legal and illegal trade co-exist and yield "normal" profits. But this possibility is ignored in the text which follows Pitt's formulation in this regard. 
(i) In this case, the model yields the LVDP price disparity with the correct inequality à la Pitt, as it should since it was specifically devised to explain such a disparity: $\mathrm{p}_{\mathrm{c} l}(1+\mathrm{t})>\mathrm{p}_{\mathrm{d}}$.

(ii) Since $\mathrm{p}_{\mathrm{c} l}^{\mathrm{t}}=\mathrm{p}_{\mathrm{cl}}$, TLVDP price disparity also follows in this model.1.

(iii) PCC price disparity will not arise: $\mathrm{p}_{\mathrm{f}}=\mathrm{p}_{\mathrm{cl}}$.

(iv) However, as in Model V, PCC quantity disparity will exist, i.e. $\mathrm{q}_{\mathrm{f}}>\mathrm{q}_{\mathrm{cl}}$, or not exist depending on whether the illegal imports are recorded in the exporting country's statistics or not.

(v) This is equally true of PCC value disparity.

(vi) Again, LI price disparity will exist since illegal trade will incur non-negligible real costs, so that $\mathrm{p}_{\mathrm{c} l}^{\mathrm{t}}<\mathrm{p}_{\mathrm{ci}}^{\mathrm{t}}$.

As for welfare impact, this will again be ambiguous since the terms-oftrade loss on illegal trade will imply a loss to be set against the gain implied by the effective lowering of the importable good's domestic price, $\mathrm{p}_{\mathrm{d}} \cdot{ }^{2}$

\section{Concluding Remarks}

In the foregoing analysis, several different forms of illegal trade are modelled, reflecting different ways in which illegal trade actually arises in the real world. The models are analyzed for their implications for conventionally-defined welfare impact as also for their implications regarding observable price, quantity or value data on trade so that the empirical analyst of illegal trade can detect the different types of illegal trade and possibly discriminate among them from the statistical evidence. The full set of results has been tabulated in the following table.

\footnotetext{
${ }^{1}$ Note of course that these LVDP and TLVDP price disparities were shown to arise in other models also in this paper.

2 Pitt also considers the case where the real costs on illegal trade are negligible. In that case, the welfare impact owing to reduced domestic price of the imported good is unambiguously favourable, of course.
} 


\begin{tabular}{|c|c|c|c|c|}
\hline 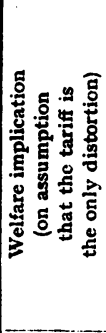 & 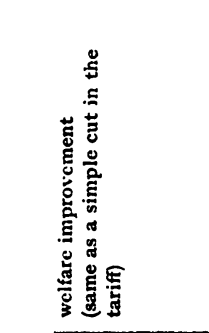 & 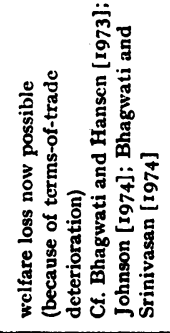 & 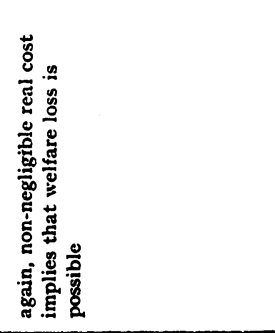 & 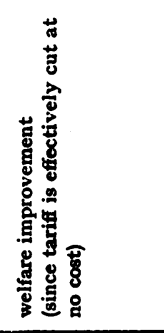 \\
\hline 굴 & $\begin{array}{l}\frac{n}{7} \\
\stackrel{2}{z}\end{array}$ & 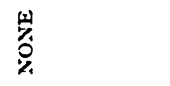 & 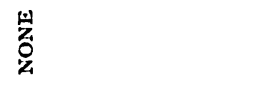 & $\begin{array}{l}\stackrel{0}{2} \\
0 \\
0\end{array}$ \\
\hline 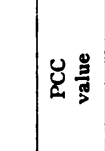 & 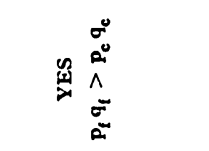 & 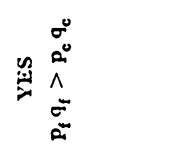 & 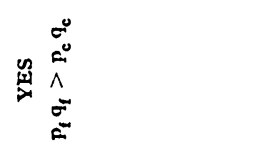 & 照 \\
\hline 尊 & 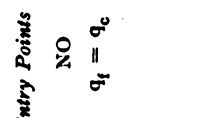 & $\stackrel{\circ}{0^{\circ}}$ & 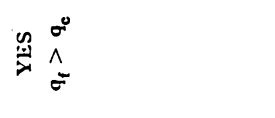 & $\stackrel{\sigma^{\circ}}{\|}$ \\
\hline 总 & 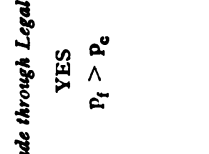 & 电 & 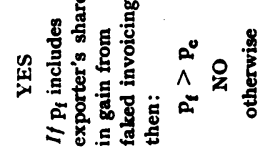 & 象 \\
\hline 量量 & 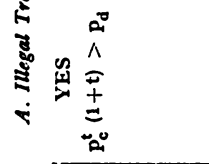 & 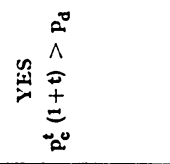 & 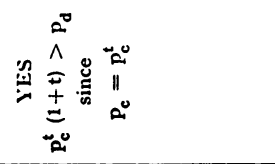 & 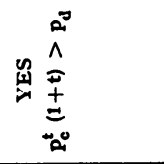 \\
\hline 岑量 & 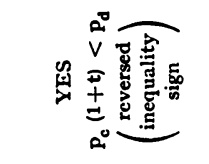 & 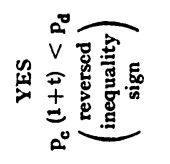 & 盆拿 & 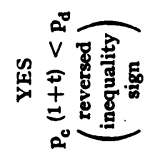 \\
\hline 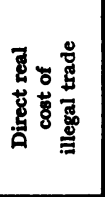 & 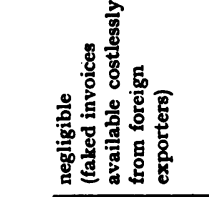 & 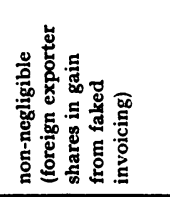 & 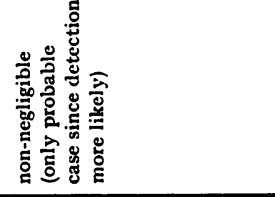 & 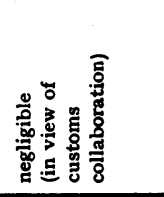 \\
\hline $\overrightarrow{\mathrm{d}}$ & 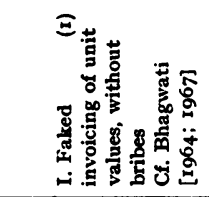 & $\widehat{\widehat{ิ}}$ & 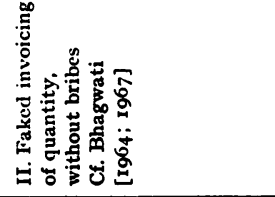 & 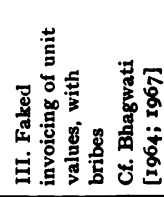 \\
\hline
\end{tabular}




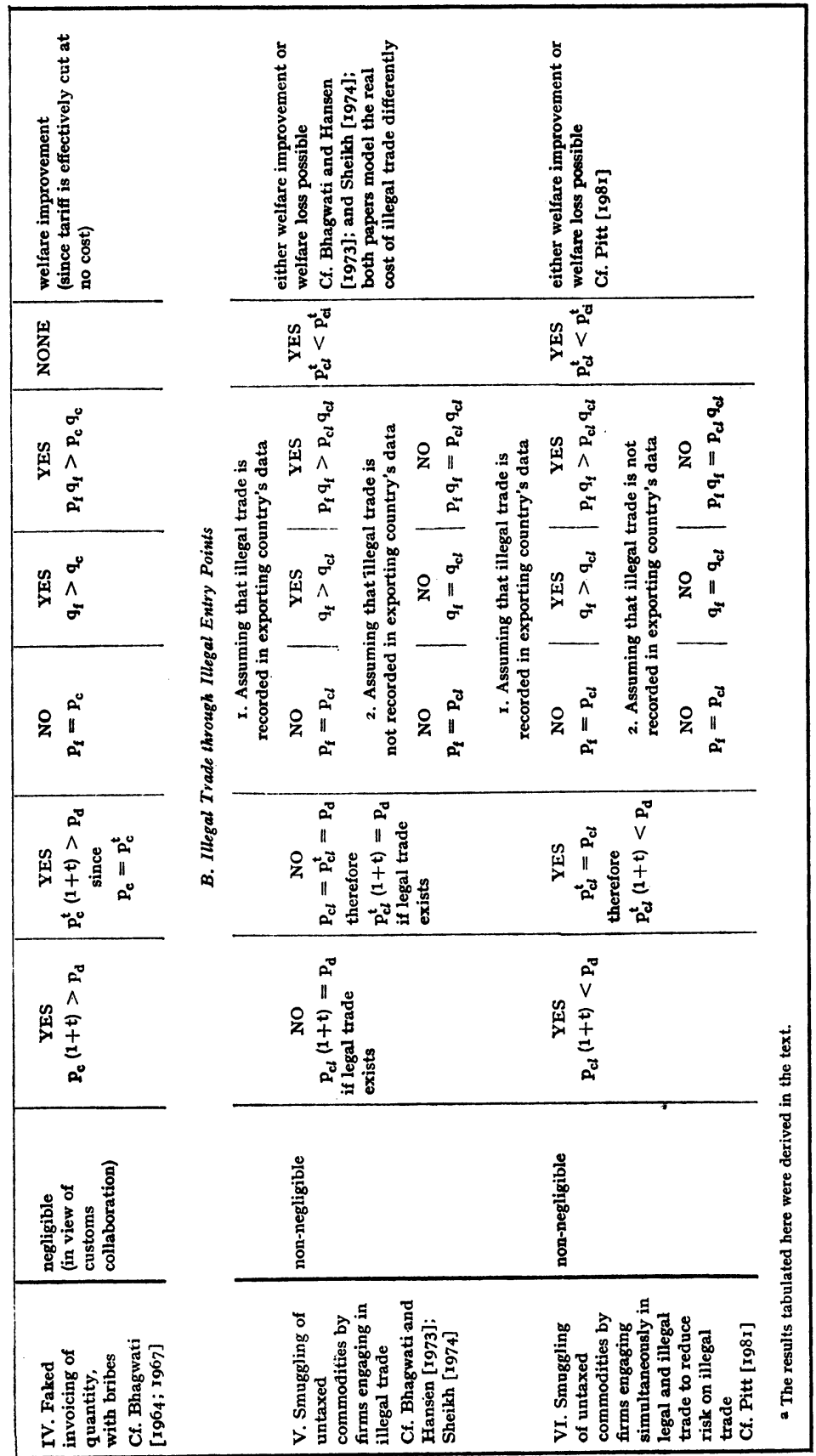

Weltwirtschaftliches Archiv Bd. CXVII.

29 


\section{References}

Bhagwati, Jagdish N., "On the Underinvoicing of Imports". Bulletin of the Oxford University Institute of Economics and Statistics, Vol. 26, Oxford, 1964, pp. 389-397.

-, "Fiscal Policies, the Faking of Foreign Trade Declarations, and the Balance of Payments". Ibid., Vol. 29, 1967, pp. 6I-77.

-, and Bent Hansen, "A Theoretical Analysis of Smuggling". The Quarterly Journal of Economics, Vol. 87, Cambridge, Mass., 1973, pp. 172-187.

-, and T. N. Srinivasan, "Smuggling and Trade Policy". In: Jagdish N. Bhagwati (Ed.), Illegal Transactions in International Trade. Theory and Measurement. Studies in International Economics, r, Amsterdam, 1974, pp. 27-38.

-, Anne Krueger and Chaiyawat Wibulswasdi, "Capital Flight from LDCs: A Statistical Analysis". In: Ibid., pp. 148-154.

Falvey, Rodney E., "A Note on Preferential and Illegal Trade under Quantitative Restrictions". The Quarterly Journal of Economics, Vol. 92, New York, 1978, pp. $175-178$.

Johnson, Harry G., "Notes on the Economic Theory of Smuggling". In: Jagdish N. Bhagwati (Ed.), Illegal Transactions in International Trade. Theory and Measurement. Studies in International Economics, I, Amsterdam, 1974, pp. 39-46.

Nayak, Satyendra S., "Illegal Transactions in External Trade and Payments in India: An Empirical Study". Economic and Political Weekly, Vol. 12, Bombay, 1977, pp. $205 \mathrm{I}-2062$.

Pitt, Mark M., "Smuggling and Price Disparity". Journal of International Economics, Vol. II, Amsterdam, I98I forthcoming.

Ray, Alok, "Smuggling, Import Objectives, and Optimum Tax Structure". The Quarterly Journal of Economics, Vol. 92, New York, 1978, pp. 509-514.

Sheikh, Munir A., "Smuggling, Production and Welfare". Journal of International Economics, Vol. 4, Amsterdam, 1974, pp. 355-364.

Zusammenfassung: Alternative Theorien des illegalen Handels: Wirtschaftliche Folgen und statistische Ermittlung. - In dem Artikel werden verschiedene Formen des illegalen Handels im Modell dargestellt und dabei verschiedene Wege, auf denen illegaler Handel in der Wirklichkeit entsteht, aufgezeigt. Untersucht werden die Modelle auf ihre Implikationen für die in konventioneller Weise definierte Wohlfahrt und außerdem im Hinblick auf die beobachtbaren Daten der Preise, Mengen und Werte im internationalen Handel, so daß der empirische Forscher die verschiedenen Arten des illegalen Handels ausmachen und möglicherweise zwischen ihnen aufgrund des statistischen Befunds diskriminieren kann.

Résumé: Théories alternatives du commerce illégal: Les conséquences économiques et la détection statistique. - Dans l'article l'auteur modèle quelques formes du commerce illégal qui reflètent les aspects différents sous lesquels le commerce illégal 
se manifeste dans le monde réel. L'analyse des modèles se concentre sur les implications pour le bien-être conventionellement défini aussi bien que sur les implications regardant les données observables de prix, de quantité et de valeur afin que l'analyste puisse découvrir les types différents du commerce illégal et possiblement différencier entre eux à l'aide de l'évidence statistique.

Resumen: Teorias alternativas de comercio ilegal: Consecuencias económicas y detección estadística. - En el análisis siguiente, se modelan diferentes formas de comercio ilegal que reflejan diferentes caminos a traves de los cuales surge el comercio ilegal en el mundo real. Los modelos se analizan con respecto a sus implicaciones sobre el impacto de bienestar definido convencionalmente como también por sus implicaciones referentes al precio, cantidad y datos de valor observables del comercio, de tal manera que el analista empírico del comercio ilegal pueda detectar los diferentes tipos de comercio ilegal y posiblemente discriminar entre ellos a partir de la evidencia empírica. 